$(100),(101)=40^{\circ} 7^{\prime},(010),(111)=55^{\circ} 26^{\prime}:$ it has a perfect cleavage (100), and like Liveingite exhibits no oblique striations on the planes in the zone $[100,001]$. The other mineral is also oblique with $\beta=89^{\circ} 40^{\prime},(100),(101)=46^{\circ} \quad 18^{\prime}$, and $(010)$, $(111)=59^{\circ} 56^{\prime}:$ it has a perfect cleavage $(100)$, and like Ratbite exhibits numerous oblique striations on the planes in the zone $[100,001]$. On fine brilliant crystals of Sartorite recently obtained by the author he has been able to confirm the oblique symmetry which he had previously announced and to determine accurately the elements $\beta=88^{\circ} 31^{\prime},(100),(101)=54^{\circ} 4 \tilde{5}^{\prime},(010),(111)=69^{\circ} 52 \frac{1}{2}^{\prime}$. Amongst other specimens from the dolomite of the Lengenbach in the Binnenthal, the author exhibited and described peculiar rounded crystals of Galena resembling Seligmannite, Hyalophane crystals twinned according to the Carlsbad law and showing three new forms, a green mica which was determined to be anorthic, Albite and Biotite, minerals which have not been hitherto recorded from the locality, and Barytes in green crystals. Of specimens from the Ofenhorn, the author exhibited some remarkably fine crystals of Anatase, and crystals of Laumontite, a mineral new to the locality.Mr. L. J. Spencer described crystals of Adamite from Chili, which were remarkable for their strong pleochroism.-Mr. G. F. Herbert Smith discussed the prismatic method of determining indices of refraction. From observations of the angles of incidence and deviation the refractive index and direction of the wave-front in the crystalline medium could be found. By using pairs of faces in the same zone and different angles of incidence a series of refractive indices is obtained, which, when plotted with the direction angle as ordinate, gives in general a double curve. Three of the critical values are the principal indices, the fourth corresponding to the direction parallel to the zone-axis. The angles of polarisation with respect to the zone-axis provide a means of discriminating between the doubtful values. A description was given of an inverted goniometer whereby observations could be made in media other than air.

\title{
OBITUARY.
}

\section{ROBERT ETHERIDGE, F.R.S. L. \& E., F.G.S.}

Bors December 3, 1819.

Died Decenher 18, 1903.

In the closing days of the old year another veteran geologist has laid aside his hammer and gone to his rest, working up to the very last of his long and active life at his favourite science.

The name of Robert Etheridge is well known to all the older geologists, and, until his retirement from the public service on the 31st December, 1891, be had been a familiar figure for 34 years in the London geological world, 24 of which he was one of the Palæontologists to the Geological Survey and Museum in Jermyn Street, while for ten years he was attached to the British Museum 
(Natural History), Cromwell Road, as Assistant Keeper of Geology. To the readers of the Grological Magazine his name must have been very familiar, having appeared on the cover as one of the Assistant Editors since the 1st July, 1865, a period of 39 years.

Mr. Etheridge was a Herefordshire man, having been born at Ross on 3rd December, 1819.

His public career may be said to have commenced with his appointment in $\mathbf{1 8 5 0}$ as Curator to the Museum of the Philosophical Society in Bristol, an office which be held with distinction for seren years. During five years of this period he also occupied the post of Lecturer in Botany in the Bristol Medical School, then a highly esteemed centre of medical instruction. He was besides a frequent lecturer on Geology and Palæontology in the Bristol Philosophical Institution. In 1856, when paying a visit to the Earl of Ducie, who is himself an excellent geologist, Mr. Etheridge was introduced to Sir Roderick I. Murchison, then Director General of the Geological Survey of Great Britain, as a promising geologist deserving of a more important post than Bristol could offer him, and in the following year (1st July, 1857) Etheridge, through Murchison's interest, was appointed to the Geological Survey as Assistant Palæontologist under J. W. Salter in the Museum of Practical Geology.

During the 24 years in which he was attacbed to the Survey, Mr. Etheridge travelled over a very large portion of the United Kingdom in assisting the younger Surveyors in their work in the field by means of his palæontological knowledge. He prepared numerous Palæontological Reports and Lists of Fossils to accompany the Memoirs of the Geological Survey upon various parts of England and Wales; he also wrote a Report on the Palæontology of Jamaica. For fifteen years he gave demonstrations annually in Palæontology to the students of the Royal School of Mines, at that time attached to the Museum of Practical Geology, Jermyn Street. With the assistance of his colleague, Mr. George Sharman, he rearranged the entire Palæontological Collection, and prepared a catalogue of the specimens which was published with a preface by Professor Huxley.

Mr. Etheridge contributed numerous papers to the Geological Society of London, which appeared in the Quarterly Journal of that Society from 1863 to 1889 ; the most important being his memoir "On the Physical Structure of North Devon," being a defence of the unity of the Deronian system, which had been disputed by Professor J. Beete-Jukes. It occupied 200 closely printed pages of the Journal, with lists of all the known fossils as well as of those personally collected in the field during an examination of the North Devon area, extending over several months.

$\mathrm{He}$ prepared a description of the Palæozoic and Mesozoic fossils of Queensland, Australia, 1872, collected by Mr. R. Daintree, F.G.S., and later on, in 1878, of the fossils brought home by the Arctic Expedition under Captain Sir George Nares, R.N., which formed a most important addition to our knowledge of the palæontology of the Polar lands. 
When President, Mr. Etheridge delivered two most valuable addresses to the Geological Society of London, that in 1881 "On the Distribution of British Palæozoic Fossils," and in 1882 "On the Distribution of British Jurassic Fossils."

His other papers include descriptions of British Oolitic and Liassic Mollusca (1863); Jurassic Fossils of the Himalayas (1864); the Rhætic beds and sections (1865-66); Geology of the Bristol Coal-Basin (1866); the Stratigraphical position of Irish Isabyrinthodonts (1866-67); the Geological position of the Bristol Conglomerate (1870); a new species of Echinoid from North Africa (1872); the Geology of the Watchet Area (1873); a Table of British Fossils, in Lyell (1874); Fossil Plants from Kosloo, Black Sea (1877) ; some New Tertiary Mollusca from Brazil (1879) ; on Lepidotus maximus (1889).

Probably the most important of Mr. Etheridge's labours bas been the preparation of a Catalogue of the Fossils of the British Isles, stratigraphically and zoologically arranged-published by the Clarendon Press, Oxford, 1888 (4to, pp. 468)-of which it is to be regretted that only vol. $i$, comprising the Palæozoic fossils, has ever appeared, vols. ii and iii being still in manuscript, although completed up to 1888. In this work the author has catalogued 18,000 species of fossils.

Mr. Etheridge was elected a Fellow of the Geological Society of London in 1854, and served on the Council from 1863 to 1868 , from 1872 to 1878 , and from 1880 to 1883 . He was elected President in 1880, and beld the office until February, 1882. He received the Award of the Wollaston Fund from the Geological Society in 1871, and the Murchison Medal and Fund in 1880.

Mr. Etheridge was President of Section C (Geology) at the Meeting of the British Association, Southampton, 1882.

He became a Fellow of the Royal Society of Edinburgh in 1855, and of the Royal Society, London, in 1871, and served on the Council of the latter Society in 1884 .

In 1890 he was elected an Honorary Fellow of King's College, London.

He has served on the Council of the Palæontographical Society for many years, and was made Treasurer in 1880, an office he retained up to the time of his death.

On the 20th October, 1881, Mr. Etheridge's services were transferred, with the sanction of the Treasury, from the Geological Survey and Museum to the British Museum (Natnral History), where, in association with his friend Dr. Henry Woodward, F.R.S., the Keeper of the Department of Geology, he occupied the post of Assistant Keeper for ten years. One of the most interesting pieces of work which Mr. Etheridge accomplished was the preparation of a Stratigraphical Collection to illustrate by sections, maps, and specimens all the British sedimentary rocks. This is exhibited in Gallery XI, and is much valued by students of geology.

Mr. Etheridge was always distinguished by his courtesy and his readiness to impart scientific information to students and the public 
at large, and he was greatly esteemed as an officer in the Museum, whilst his energy and activity of disposition enabled him to accomplish a very large amount of scientific work daily.

He retired from office at the end of 1891 (under Clause $X$ of the Order in Council of 15th August, 1890). He continued, however, to be employed by the Trustees until the 31st March, 1893, when the Treasury vetoed any further engagement. A year later, on the 26th April, 1894, his old colleagues and friends, to the number of 85, gave him a complimentary dinner at the Imperial Institute, the chair being taken by Sir William Flower, K.C.B., the Director of the Museum of Natural History.

In 1896 he was presented with the first Bolitho gold medal by the Royal Geological Society of Cornwall in recognition of his distinguished services to greology, especially in the Western Counties.

But his retirement from office by no means retarded his scientific work, for he continued independently to pursue his genlogical and palæontological labours up to the close.

He devoted much of his time during the last twelve years to the duties of Consulting Geologist to the Dover Coal Boring, and patiently and accurately recorded foot by foot every core and sample of material brought to bank by the engineers. Many of these specimens are deposited in the Geological Department, British Museum (Natural History), where he continned to carry on his researches up to the end. He was deeply interested in the Coal Commission, was a well-known authority on the Bristol Coalfield and on that of the Kentish and the Franco-Belgian area, which he bad carefully studied. In 1897 he read a paper before the Engineering Conference on "The Kent Coalfield," in which he affirmed his belief in the existence of an extensive and valuable coalfield in the South-East of England or near Dover, and explained its relation to the coalfields of the South-West of England (Bristol and Somerset), and to those of the North of France and Belgium. $\mathrm{He}$ made excursions to Belgium, Germany, and Austria, examined the volcanic phenomena of the Auvergne and of the Eifel districts, and wrote a short account of his visit to Central France.

$\mathrm{He}$ was an authority upon water-supply, and was frequently associated with the late Mr. Hawksley and his son, Mr. Charles Hawksley, M.I.C.E., and other eminent Civil Engineers, in connection with supplies for Bristol, Plymouth, London, and other large centres of population.

Mr. Etheridge was anthor of a Report, dated 22nd June, 1857, on Thames Mud and Thames Water, being based upon a microscopic examination of eighteen samples of mud and detrital deposits and two or more samples of water taken from the River Thames; giving a detailed account of each sample, both for the living organisms, the organic matter in a state of decomposition, and the inorganic mineral residuum; issued as Appendix II to Report relating to the Main Drainage of the Metropolis (folio, pp. 61-72). Ordered to be printed by the House of Commons, 3rd August, 1857.

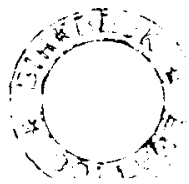


He was also engaged to prepare Maps and Sections, and to give evidence before the "Royal Commission on Coal" (13th March, 1868) in relation to the Somersetshire Coalfield, and especially in reference to the probability of finding coal under the Permian, New Red Sandstone, and other superincumbent strata. [See Report of the Royal Commission on Coal, vol. i, pp. 419-422 (D. 7-10), folio ; 1871.]

He leaves an only son, Mr. Robert Etheridge, jun., who bas oceripied the post of Curator of the Australian Museum, Sydney, N.S.W., since 1887, and was from 1879 to 1887 an Assistant under Dr. H. Woodward, F.R.S., in the British Natural History Museum, London, and previously on the Geological Survey of Scotland, with Sir A. Geikie, F.R.S. Like his father, Mr. Robert Etheridge, jun., is a distinguished palæontologist and geologist, and commenced his career as one of the staff of the Geological Survey of Victoria, Australia, under the late Dr. A. R. C. Selwyn, F.R.S.

Among his other literary labours it may be mentioned that Mr. Etheridge greatly assisted Dr. J. J. Bigsby, F.R.S., F.G.S., in the preparation of his great works (see author's prefaces to works) (a) "Thesaurus Siluricus," 1868, 4to, pp. 268; (b) "Thesaurus Devonico-Carboniferus," 4to, 1878, pp. 450. He edited the third edition of Part $i$ of "Illustrations of the Geology of Yorkshire," 4to, 1875, pp. $\mathrm{x}$ and $3 \tilde{0} 4$, by Professor John Phillips, F.R.S., who died 24th April, 1874. He also assisted Mr. J. W. Lowry to construct his Chart of Characteristic British Tertiary Fossils, stratigraphically arranged; London, E. Stanford, 1866.

Mr. Robert Etheridge was a Corresponding Member of the Imperial Institute of Vienna, an Honorary Member of the Geological Society of Belgium, of the New Zealand Institute, the Royal Geological Society of Cornwall, the Philosophical Societies of Yorkshire and Bristol, the Geologists' Association, the Norwich Geological Society (since defunct), the Cotteswold Naturalists' Field Club, of the Hertfordshire Natural History Society, the Dorset Natural History and Antiquarian Field Club, and the Northamptonshire Natural History Society and Field Club.

A severe cold and an attack of bronchitis terminated his busy and useful life after a brief illness of three days.

\section{List of Titles of Works and Memorrs by Robert Etheridge,} F.R.S. L. \& E., F.G.S.

1. "Geology; its Relation and Bearing upon Mining." (Lectures, Bristol Miningr School.) 8ro; Bristol, 1859.

2. "Descriptions of new species of Mollusca, etc." [Ceromya gibhosa, Astarte dentilabrum, and Pollicipes liassicus]: Quart. Journ. Greol. Soc., vol. xx (1864), pp. 112-114.

3. "Note on the Jurassic Fossils collected by Captain Godwin-Austen" [in the N.W. Himalayas]: Quart. Journ. Geol. Soc., rol. xx (1864), pp. 387-388.

4. "On the Rhætic or Aricula contorta Beds at Garden (liff, Westbury-uponSevern, Gloucestershire" : Proc. Cotteswold Club, vol. iii (1865), pp. 218-234.

5. "A Catalogue of the Collection of Fossils in the Museun of Practical Geology, Jermyn Street." (Preface by Professor Huxley, pp. i-lxxix.) Catalogue, pp. 1-382. 8vo. 1865 . 
6. "On the Palnontology of the Caribbean Area," being Appendix V to the Geology of Jamaica, by Jas. G. Sawkins, F.G.S., 1866. 8vo; pp. 306-339. (Published as a Colonial Memoir of the Geological Survey.)

7. "Section of the Rhatic Beds at Aust Cliff", ; Proc. Cotteswold Club (1866), pp. 13-18.

8. "On the Phirsical Structure of the Northern Part of the Bristol Coal-Basin, chiefly having reference to the Iron Ores of the Tortworth Area": Proc. Cotteswold Club (1866), pp. 28-49.

9. " On the Discovery of several new Labrrinthodont Reptiles in the Coal-measures of Ireland": GEof. MAG., Vol. III (1866), pp. 4-5.

10. "On the Strationaphical Position of Acanthopholis horridus, Huxley" : Geoc. MAG., Tol. IV (1867), pp. 67-69.

11. "On the J'hwical Structure of North Devon, and on the Palacontological Value of the Devonian Fossils": Quart. Jouru. Geol. Soc., vol. xxiii (1867), pp. 251-252, abstract, (full text) 568-698; Phil. Mag., vol. xxxiv (1867), pp. $317-318$.

12. "Supposed P'ermian Beds at Portskewet": Proc. Cotteswold Club, rol. iv (1568), p). $.256-258$.

13. "On the Geolugical Poition and Gonrraphical Distribution of the Reptilian or" Dolomitic Conmlomerate of the Bristol Area,": Quart. Journ. Geol. Soc., wol. xxvi (1870), p]). 174-191 ; 1hil. Mag., vol. xi (1870), pp. 136-137.

14. "I)escription of a new genus (Rotuloidea) of Fossil Scutelloid Eehinodern from Siffe, X. Airicil": Quart. Jouru. Geol. Soc., vol. xxriii (1872), pp. $97-101$.

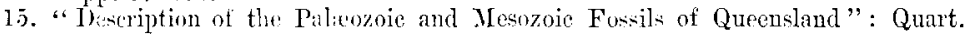
Journ. Geol. Soc., vol. xxviii (18-2), pp. 317-350, pls. xiii-xxviii.

16. "On the Rhatic Beds of Penarth and Lavernock": 'Trans. Cardiff Nat. Soc., rol. iii (18\%2), pp. 39-64.

17. " Totem upon the I'lycical Structure of the Watchet Area, and the Relation of the Secondary Rocks to the Deronian Series of West Somerset"' Proc. Cotterwoll (ilub, vol. vi $(1873)$, pp. $35-49$.

15. "lable of British Fusils illustrative of the Successive $A$ ppenrance and Development in 'Time of the Chict Orolers, Clisses, or Families of Animals and Plants in Britain": p p. 623-645. Printed as a Supplement to Sir Charles Lyoll's Students' Elonents of Goology, 2nd ad., 1874; 3rd ed., 1878.

19. Appendix. [Hecozoic fossils found by the Rev. J. E. Cross in X.W. Lincolnshire.] Quart. Journ. Geol. Soe., rol. xxxi (1875), pp. 126-129.

20. "Notes on the Fossil l'lant from Kosloo" [Black Sea]: Quart. Journ. Geol. Soc., vol. xxxiii (1877), pp. 532-533.

21. "Palaontology of the Coasts of the Aretic Tands visited by the late British Expedition under Capt. Sir Georse Nares, K.C.13.": Quart. Journ. Geol. Soc., vol, xxxir (18;s), pp. 568-636, pls, xxv-xxix.

22. " Notes on the Mollusta collected by C. Barrington Brown, Esq., from the 'Tertiary I) eposits of the Solimöes and the Javary Rivers, Brazil", Quart. Journ. Geol. Soc., vol. xxxr (1879), pp. 82-88, pl. rii.

23. Presidential Address to the Grologieal Society of London, Feb. 18, 1881, "On the Analyis and Distribution of the British Paleozoic Fossils": Quart. Journ. Geol. Soc., rol. xxxrii (1881), Proceedings, pp. 37-235.

24. "On a New sipecies of Trigonia from the Purbeck Beds of the Tale of Wardow": Quart. Journ. Geol. Soc., vol. xxxrii (1881), pp. 246-248.

25. Appendix. [Nematophycus Hichsii.] Quart. Journ. Geol. Soc., vol. xxrrii (1881), pp. $490-495$.

29. Presidential Addres to the Geological Societr of London, Feb, 17, 1882, "On the Analvis and Distribution of the British Jurassic Fossils" : Quart. Journ. Geol. Soc., vol. xxxviii (1882), T'roceedings, pp. 46-236.

27. Iresidential Address to the Geological Section of the British Association, Southampton, August 23,1882 .

28. "Stratioraphical Geology and Palmontology" (being a new and revised edition of 1'hillips's Manual, entirely rewritten). 1885. 8\%o; pp. 712, with 33 plates.

29. "Fossiis of the British Islands, Stratigraphically and Zoologically arranged": rol. $\mathrm{i}$ (1888), l'alionosic Species. 4to; pp. viii and 468 .

Vol. ii, Mesozoic, and rol. iii, Cainozoic, completed, but still in manuscript. 
30. (With Mr. H. Willett) " On the Dentition of Lepidotus maximus (Wagner), as illustrated by specimeus from the Kimeridge Clay of Shotover Hill, near Oxford": Quart. Journ. Geol. Soe., vol. xlv (1889), pp. 356-358, pl. xv.

31. Letter on Dr. Wheelton Hind's Carboniferous Lamellibranchiata: Geoc. Mag., Dec. IV, Vol. IV (1897), p. 94.

32. "On the Relation between the Dover and Franco-Belgrian Coal Basins": Rep. Brit. Assoc. for 1899 (1900), pp. 730-734.

Grological Survey Memoirs to which Mr. Etheridge has contributed the Paleontology.

1. 1858. Geologr of parts of Wilts and Gloucestershire (Sheet 34). Iist of Fossils by R. Etheridge.

2. 1859. Geology around Wookstock, Oxon (Sheet 45). List of Fossils by R. Etheridge.

3. 1860. Geologs of part of Leicestershire (Sheet 63). Iist of Fossils by R. Etheridue.

4. 1861. Geology of part of Northampton and Tarwick (Sheet 53). List of Fossils by R. Etheridge.

5. 1862. Geology of the Isle of Wight (Sheet 10). Jist of Fossils by R. Ftheridge.

6. 1862. Geology of part of Berks and Hants (Sheet 12). Jists of Fossils by R. Etheridge.

7. 1864. Geology of Banbury, Woodutock, ate. (Sheet 45). Jists of Fossils by R. Etheridge.

S. 1875. Geology of the Bumler Coalfield (Shcets 88, 89, and 92). Table of Fossils by R. Ftheridge.

9. 1875. 'The Geology of the Weald, by W. Topley, F.G.S., ete. I ists of Fossils by R. Etheridge.

10. 1875 . The Geologr of Rutland, by J. W. Judd, F.G.S. Appendix and Tables of Foseisi by R. Etheridue.

11. 1876. Geologr of Eist Somerset, by 1I. B. Wondward, F.G.S. Lists of Fossils by R. Ftheridge.

12. 1876. Geology of the Take District, by J. C. Ward, F.G.S. Appendix on New Species of Fossils by R. Etheridge.

13. 1877. Superficial Geolony of South-West Jancuhire, by ( $\therefore$ E. De Rance, F.G.S. Idists of Fussils revised by R. Etheridge.

14. 1878. Catalogue of the Cambrian and Silurian Fossils in the Museum of Practical Geology (the "Wratt-Ederell (Collection"). "The specimens have been named by Mr. Etheridge, F.R.S., Pakoontologist to the Geological Surver." The Catalogue drawn up by Mr. E. T. Newton, F.G.S.

15. 1880. Geology of the South of Scarborough (Shect 95). Jint of Fossils revised by R. Etherilige.

16. 1881. Geology of the Country round Norwich (Shet 66). Tist of Fossils revised by $R$. Etheridge.

17. 1881. Geology of the Golitic and Liassic Rucks, Maltm. Jists of Fossils revised by li. Fithridge.

18. 1881. Geologr of the Neirhbourhood of Cambridgre. Talirontolngical Appendix by R. Etheridge.

19. 18si. Geolocy of North Walcs, by A. (. Ramsay, F.R.S. (cecond edition). J. W. Salter's Appendix on the Fossils, reviod and greatly enlarged by R. Etheridge (pp. 351-567).

Note.-Althongh, owing to Mr. Etheridge's death baving occurred so very near before Christmas, the Publishers were prevented from issuing a portrait of him in this (January) Number, yet his friends will, we feel sure, be glad to be informed that an excellent and, as yet, unpublished photograph of him-quite lately taken by Miss Constance E. Power (daughter of Edward Power, Esq., one of Mr. Etheridge's oldest and most valued friends)-will appear in the February Number of the Grological Magazine.-B. W. 

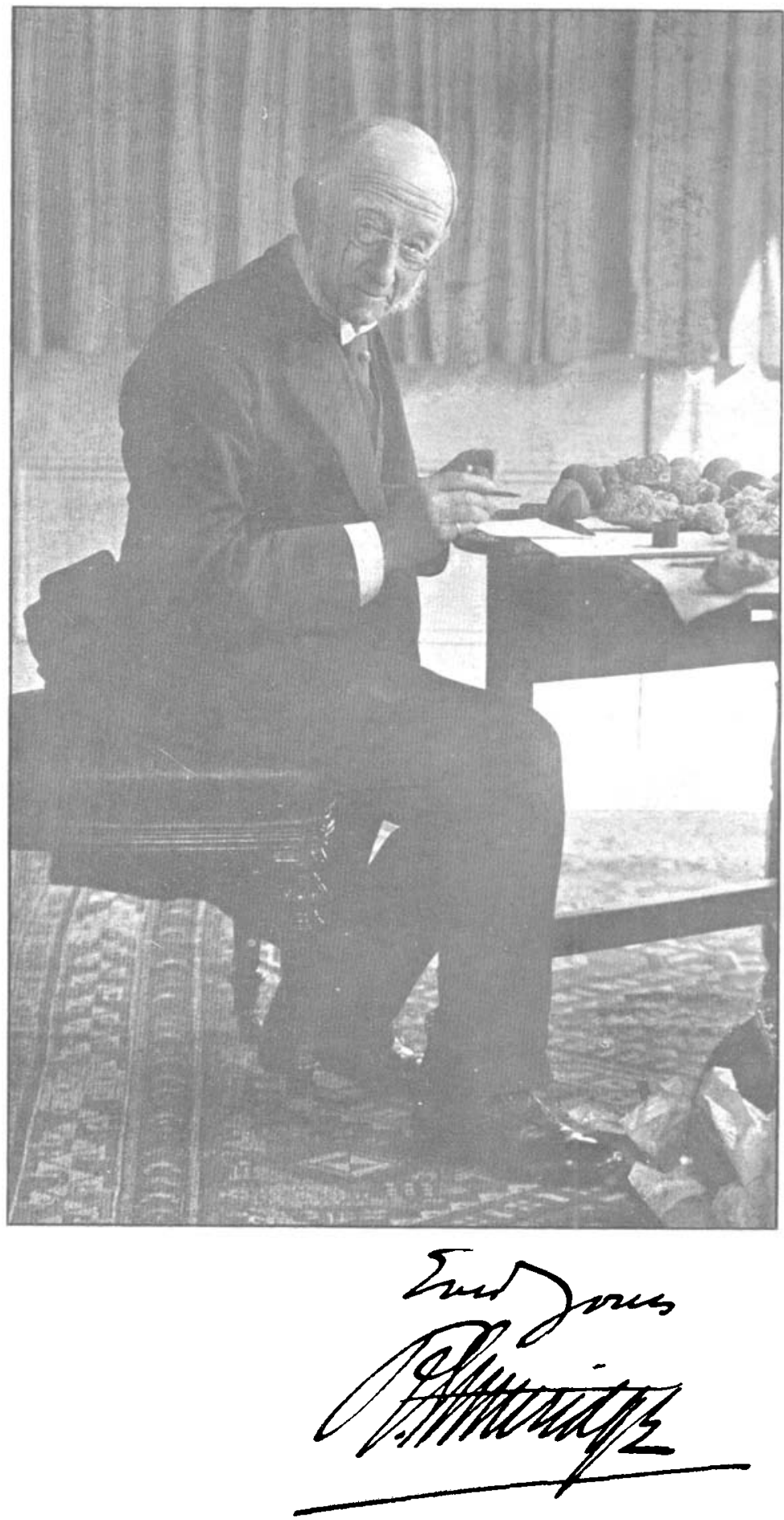